\title{
Analysis of Aluminium Alloy Wheels Product Quality Improvement Through DMAIC Method in Casting Process: A Case Study of the Wheel Manufacturing Industry in Indonesia
}

\author{
Edna Maryani, Humiras Hardi Purba, Sunadi* \\ Industrial Engineering Department, Mercu Buana University, Jakarta 11650, Indonesia
}

Corresponding Author Email: sunadi210770@gmail.com

https://doi.org/10.18280/jesa.540107

Received: 28 September 2020

Accepted: 3 February 2021

\section{Keywords:}

quality, DMAIC, capability, alloy wheels, improvement, sigma level

\begin{abstract}
The global market demand for automotive wheels with alloy materials is $55 \%$, which is quite high compared to other materials such as steel, magnesium, chromed, and carbon fiber. The high competition of the global alloy wheels market demands to be able to offer quality alloy wheels. The purpose of this research is to reduce the number of defects in the casting process step by using the Define Measure Analyze Improve Control (DMAIC) method. This study shows the systematic approach to find the root cause of major defects in aluminum castings using the defect diagnostic approach as well as cause and effect diagram. Quality improvement using quality tools, namely the Pareto diagram, fishbone diagram. The major defects for the rejections during production were identified as leak defects, porosity motive holes, and oval defects. In determining the proposed quality improvements using the FMEA tool. The results of data processing on the calculation of process capabilities and product performance show improvements after quality improvements in the casting process. Product performance from DPMO $=15.462$, sigma level $=3.6$ to $\mathrm{DPMO}=8.186$ and sigma level $=3.9$. The effect of decreasing the percentage of defects could save production costs by IDR 413.350.000. Therefore, the application of the DMAIC method can provide a significant improvement in product quality and impact on production cost savings.
\end{abstract}

\section{INTRODUCTION}

Discussing car wheel products is certainly inseparable from the car itself. The market potential for alloy wheels or wheels is directly proportional to the vehicle sales prospects. That is the more vehicle sales, the greater the potential to increase the sale of alloy wheels. World vehicle sales data can be seen in the following graphic picture:

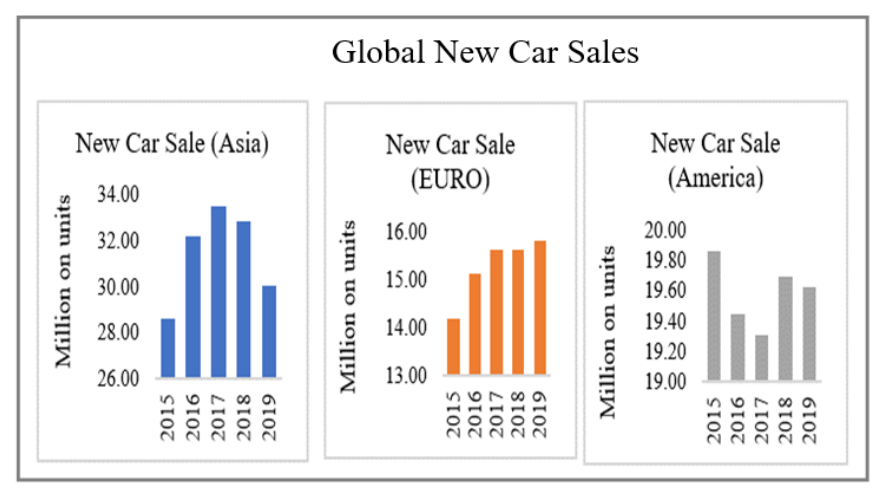

Figure 1. World car sales 2015-2019

Source: Verband der Automobilindustrie, VDA (2020)

Figure 1 shows that new car sales from 2017 to 2019 have a downward trend in new car sales. In 2019, car sales in Asia fell $2.8 \%$ compared to 2018, while in America it was relatively stable around $19.6 \%$. However, sales of new cars in Europe in
2019 were $15.8 \%$, which means there is a $0.18 \%$ percent increase over 2018. Although the world of automotive sales is declining, there is still a potential market for the sale of automotive component wheels because aftermarket wheels have many models and tend to be "fashion" for vehicle owners. Besides, in some countries with 4 seasons, namely winter, spring, summer, and fall, vehicle owners should change wheels at every change of season. And it has been a 4 season community character, if you change the tire, you will also change the wheels.

Aluminum wheels (alloys) consist of aluminum, magnesium, and nickel alloys which allow for stronger durability with lighter weight. Also, this type of wheel is easier to shape into various types of designs. Both of these factors, durability, and design, make this type of wheel most popular. The wheels are made by casting technique, the production process flow consists of three parts, namely foundry process flow, machining process flow, and machining process flow. The wheel material is heated until melted and then poured into the wheel mold. After that, the finishing is done, which is to clean the rough surface then apply paint.

Surface defects in aluminum die castings can result from deficiencies at any stage of the manufacturing process. The prevention of surface defects is a key requirement when producing most aluminum die castings. The prevention of defects related to the casting process can best be achieved through proper design of the die and feed system and control of the variables associated with the die casting process.

Quality is following the requirements, the concept of 
compliance with Crosby requirements describes a set of conditions that must be met in a way required by specifications or standards. In general, if these specifications are not met, the product is considered non-compliant and defective [1]. Quality improvement can affect the success of a business [2]. The ability of the process to produce products that meet the specifications if the process has good capabilities, then the process will produce products that are within the specification limits between the lower and upper specification limits [3]. Manufacturing companies will try to increase productivity to be able to compete and compete to get the market to make as much profit as possible with improve product quality and minimize costs incurred [4]. Companies can reduce the level of product damage in increasing productivity to save production costs [5].

The DMAIC structured repair procedure is used to solve more complex quality problems and with unknown causes [6]. The Analysis phase evaluates the operation of the current process to determine the potential source of variation for critical performance parameters. Process improvements are planned and implemented and benefit analysis is done in the Enhancing phase, solutions are documented and monitored through statistical process handling methods in the Operation phase [7]. The DMAIC method approach is used in the strategy to achieve process improvement and excellence in enterprise organization, selection of critical parameters as a step to analyze important success factors in improving product quality [8]. One method that can be employed as a problemsolving tool to overcome machine breakdowns is the DMAIC approach. DMAIC analysis to support the development of the hot rolling mill machine's capability and elimination of downtime in one of the processes in the aluminum industry [9].

As a management system, the DMAIC method is used to ensure critical improvement opportunities, developed through metric methodologies and levels in line with the company's business strategy [10]. The industrial unit to strengthen the control charts presently at their disposal, it could raise the odds to notice more nonconformities [11]. Control charts are very useful in manufacturing, administration, and service functions, control diagrams provide quick feedback on key variables [12]. FMEA is a systematic analysis of potential failure modes aimed at preventing failures. It is intended to be a preventive action process carried out before implementing new or changes in products or processes [13]. The long-term goal is to completely eliminate every single failure. The short-term goal is to minimize the failures, if not eliminate them [14]. The t-test is a statistical test used to test the truth or falsity of a null hypothesis. The purpose of this t-test is to determine the differences between the two independent groups. The principle of independent sample t-test is to see the difference of variation of two data groups and in testing the variance information of both groups is required [15].

Research learning can be done by researching and learning previous research related to the same research, with the object of automotive component research [16]. Six Sigma can be seen as a systematic and organized, customer-oriented methodology that aims to improve the performance and quality of processes, products, and services using statistical techniques and the scientific method to analyze data and make decisions [17]. The generic problems of alloy wheel machining and subsequently details on the process improvement of the identified critical-to-quality machining characteristic of aluminum alloy wheel machining process [18]. Casting parameters are optimized in order to achieve better properties [19]

The systematic approach to finding the root cause of major defects in aluminum castings using defect diagnostic approach as well as cause and effect diagram [20]. The intelligent and systematic approach to diagnose the root cause of potential defects in aluminum castings using quality tools [21]. DMAIC (Six Sigma) one method used for analyzing defective products and the FMEA method is an option in implementing corrective action in the hope that the process of building a defective product can be properly controlled by the company's schedule [22]. The application of FMEA in this analysis of breakdown machine problems was more focused than in the analysis using the Cause and Effect diagrams and Pareto diagram tools only [23].

\section{METHODOLOGY}

Six Sigma as an orderly parallel structure to reduce variation in organizational processes by using improvement experts, structured methods, and performance metrics to achieve strategic goals. The D-M-A-I-C (Define-MeasureAnalyze-Improve-Control) structured repair procedure is used to solve more complex quality problems and with unknown causes [24]. DMAIC is a closed-loop process that eliminates unproductive steps, often focuses on new measurements, and applies technology for continuous improvement [25]. This method is based on process improvement according to the Deming cycle. Figure 2 shows a clear description of the DMAIC steps.

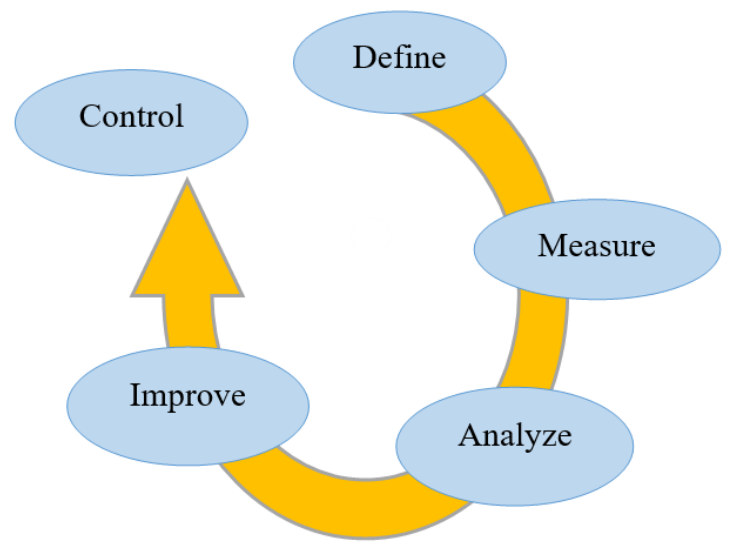

Figure 2. The DMAIC process

Define phases identifying processes or products that need improvement, while the Measurement phase identifies and measures processes and product features that are critical to customer satisfaction. The Analysis phase evaluates the operation of the current process to determine the potential source of variation in critical performance parameters. Then process improvements and product features are planned and implemented. The next stage in the Enhancing phase is to analyze the costs and benefits, then the solution is documented and monitored through the method of handling statistical processes in the operating phase. By increasing car sales increase, the demand for alloy wheels will also increase so that companies must improve the quality of their products to compete in the global alloy wheels market. The DMAIC cycle consists of five stages that are connected, every step to solve the quality control problem are as follows (Table 1): 
Table 1. DMAIC tools used in various phase

\begin{tabular}{ll}
\hline Phase & \multicolumn{1}{c}{ Meaning and Tools } \\
\hline Define & $\begin{array}{l}\text { This step is to identify the process or product that } \\
\text { needs to be improved. It will be selected, including } \\
\text { the cost, benefit, and impact for the customer. The } \\
\text { common tools are used such as 5W 1H, VOB, } \\
\text { CTQ }\end{array}$ \\
\hline Measure & $\begin{array}{l}\text { This step is to knowing or to measure the problem } \\
\text { was defined. The common tools are used such as p } \\
\text { chart, Cp, determine UCL and LCL, calculate } \\
\text { product performance DPO, DPMO, sigma level. }\end{array}$ \\
\hline Analyze & $\begin{array}{l}\text { This step to analyze the gap for existing conditions } \\
\text { vs defined goals. The tools are command use such } \\
\text { as Pareto diagram, fishbone diagram, 4M+1E, or } \\
\text { Why Why analysis }\end{array}$ \\
\hline Improve & $\begin{array}{l}\text { This step is used to do improvement which was } \\
\text { defined. The tool used in this step is FMEA } \\
\text { analysis }\end{array}$ \\
\hline Control & $\begin{array}{l}\text { To supervise improvements with a control plan, } \\
\text { SOP, measurement \& control of process } \\
\text { performance, product performance, sigma level, } \\
\text { and t-test }\end{array}$ \\
\hline
\end{tabular}

The study framework of this research is as shown in Figure 3.

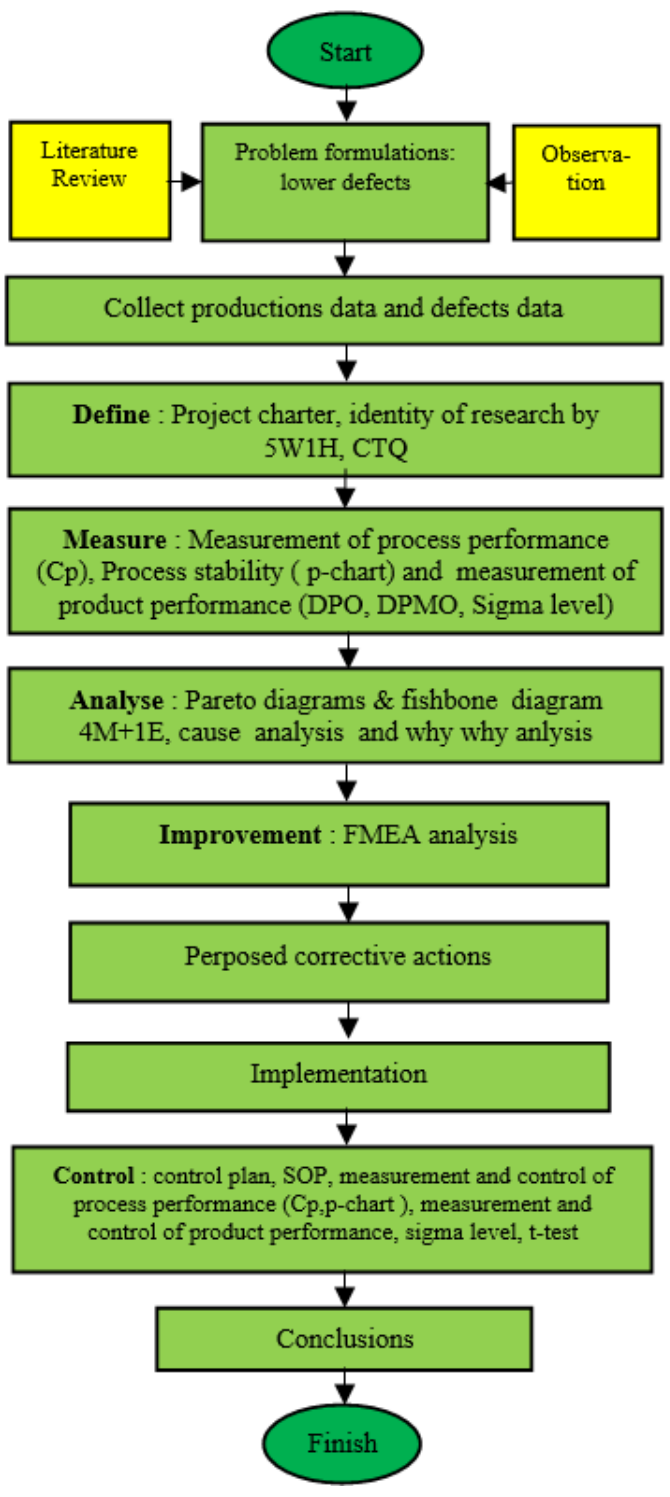

Figure 3. Study framework
The methodology used to build the work is based on the combination of keywords in several databases. This research started with the formulation of the problem, which is how to reduce the level of defects because it was found that there are many defects on the alloy wheels. Then, secondary data are collected, such as data on production volume, and type of defect. Next, data analysis is performed and DMAIC measures are performed to solve the quality control problem. The contribution of the framework study for this research can be clearer and can be handled and tested in research. This contribution is like presenting a concept for action.

\section{RESULTS AND DISCUSSIONS}

In this study, the DMAIC step method is used to simplify the repair process, as well as using quality tools as well as calculation and statistical methods at each step.

\subsection{Define phase}

At the defined stage, the identification of the problem encountered is done, this stage is very important so that the process of experiencing the problem can be understood so that appropriate improvement can be made. Determine the CTQ of the casting process based on customer requirements. This information will help to move planning by telling us if the existing business process has the potential to deliver quality levels that meet project goals. Each defect and a detailed explanation of the defect, as in the following Table 2 :

Table 2. Mapping of defect types

\begin{tabular}{|c|c|c|c|}
\hline No. & $\begin{array}{c}\text { Defect } \\
\text { types }\end{array}$ & Defect details & Pictures \\
\hline 1. & $\begin{array}{l}\text { Leak } \\
\text { defects }\end{array}$ & $\begin{array}{l}\text { Hole defects in the abdomen } \\
\text { of the wheel }\end{array}$ & \\
\hline 2. & Frontal & $\begin{array}{l}\text { Wheel defects if the standard } \\
\text { front outlet is }>+/-1 \mathrm{~mm}\end{array}$ & \\
\hline 3. & $\begin{array}{l}\text { Porosity } \\
\text { back } \\
\text { spoke }\end{array}$ & $\begin{array}{l}\text { Defects of rear wheelchair } \\
\text { area }\end{array}$ & \\
\hline 4. & $\begin{array}{l}\text { Porosity } \\
\text { motive } \\
\text { holes }\end{array}$ & $\begin{array}{l}\text { Small hole defects, wheels } \\
\text { offset needle hole area }\end{array}$ & \\
\hline 5. & $\begin{array}{l}\text { Oval } \\
\text { defects }\end{array}$ & $\begin{array}{l}\text {-Outer lip diameter } \\
\text { difference }>1.5 \mathrm{~mm} \\
\text {-Difference of outer lip } \\
\text { thickness Cst- } 1>1 \mathrm{~mm} \text { and } \\
\text { Cst- } 2>1.5 \mathrm{~mm} \\
\text {-Top, bottom and centralized } \\
\text { inserts } \\
\text {-Cst- } 1 \text { contour thickness } \\
\text { difference }>1 \mathrm{~mm}, \text { Cst }-2> \\
1.5 \mathrm{~mm}\end{array}$ & \\
\hline 6. & $\begin{array}{l}\text { Balan- } \\
\text { cing }\end{array}$ & $\begin{array}{l}\text {-Difference of outer lip } \\
\text { thickness Cst- } 1>1 \mathrm{~mm} \text { and } \\
\text { Cst- } 2>1.5 \mathrm{~mm} \\
\text {-Top, bottom and centralized } \\
\text { inserts } \\
\text {-Cst- } 1 \text { contour thickness } \\
\text { difference }>1 \mathrm{~mm} \text {, Cst }-2> \\
1.5 \mathrm{~mm}\end{array}$ & \\
\hline
\end{tabular}




\subsection{Measure phase}

Process performance in the production process is obtained from products that are critically to quality, required $\mathrm{p}$ - control charts related to parts of products that are inappropriate or defective. Then calculate the process capability $(\mathrm{Cp})$ based on attribute data, i.e., the process capability of producing nondefective products in the production process. The graph of production data control before quality improvement is as follows:

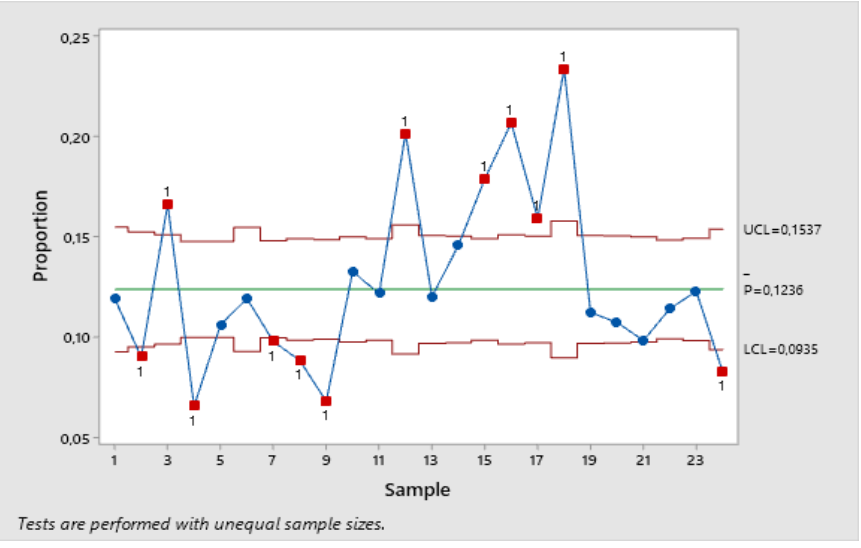

Figure 4. P-chart of the casting process

In Figure 4, the p-chart graph shows that the production process of car wheels is stated to be unstable because 12 points were found to cross the statistical control limit. These points are $2,3,4,7,8,9,12,15,16,17,18,24$ in the data for the total defects in December 2019.

The pre-increase disability percentage rate was $12.8 \%$, while the company's target disability percentage was $8 \%$, so there was an increase in the disability percentage of $2.8 \%$. The capabilities process is 0,81 , DMPO measurement is 15,462 and the sigma level is 3.6. This indicates that there is still a chance for a possible increase to reduce the number of defects and increase the level of sigma.

\subsection{Analyze phase}

At the Analysis stage, it is done to find the cause of the damage, so at this stage more clearly used Pareto diagrams and cause and effect diagrams. Making a Pareto diagram will show the main problems and the order of priority of some of the most dominant types of defects in the cause of the casting process, as in the following Figure 5.

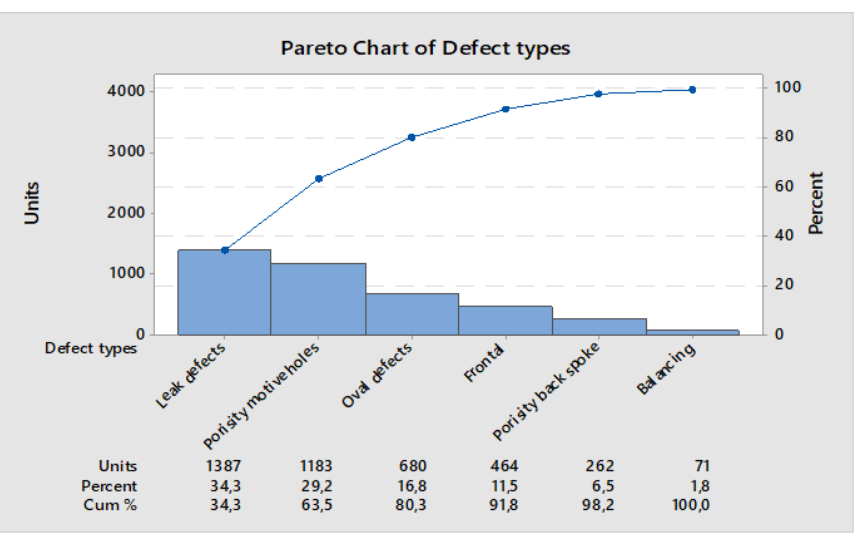

Figure 5. Pareto chart of defect types
Figure 5, it can be seen that there are 6 types of defects in the process due to casting, with the highest number of defects occurring on leak defects of $34.3 \%$, porosity motive holes of $29.2 \%$, oval defects of $16.8 \%$, the total number of three types of defects to $80.3 \%$. Three types of defects are preferred to improve production quality.

The Pareto chart contains columns arranged in descending order of the highest number of alloy wheel defects and the line diagram represents the cumulative percentage of the total defects. The Pareto chart highlights the biggest factors in a data set. The three causes of disability will be found in the following causes by analyzing the cause and effect diagram as follows:

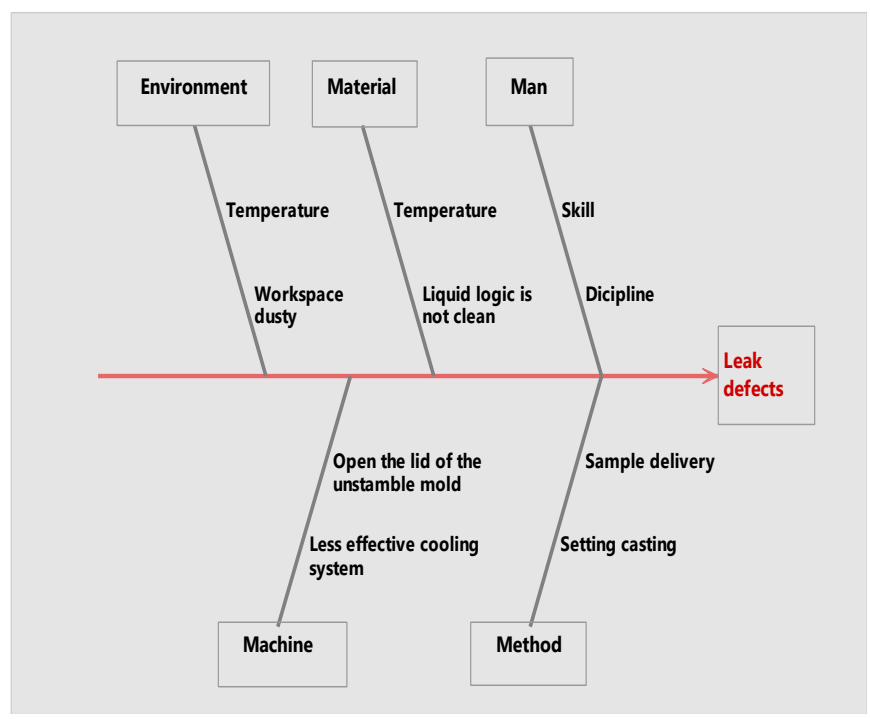

Figure 6. Cause and effect diagram of leak defects

The machine factor is due to the condition of the molding machine in the unstable movement of the mold opening and the ineffectiveness of the cooling system is not optimal. Method factors are due to how process parameters are set and applied, how to send samples for X-Ray examination, and rules for the X-Ray examination.

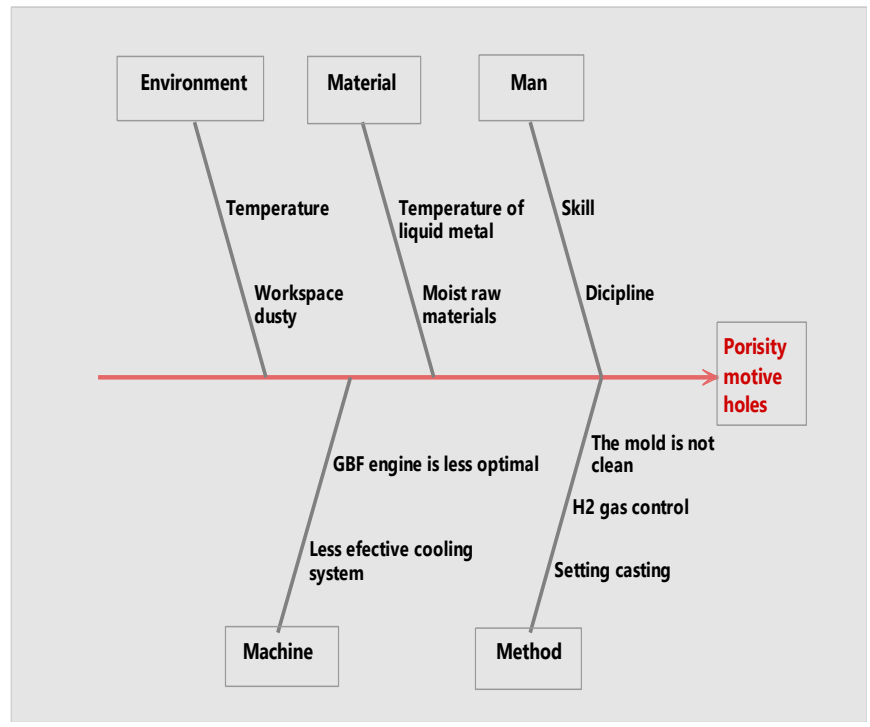

Figure 7. Cause and effect diagram porosity motive holes

Man factors are due to a lack of skilled operators, experience, and discipline. The engine factor is due to the 
effectiveness of the cooling system on the bottom mold and degassing device. The casting machine has not been installed with a water flow meter.

The machine factor is due to the pins on the upper mold and the bottom mold which are not in the middle position and some are damaged. Molding machines with hydraulic pressure and speed conditions for lateral mold movement are not the same as each other. The method factor is due to the procedure of how to correct the incorrect position of the mold.

Based on the analysis of the causes and consequences of leakage defects, porous defects, and oval defects (Figure 6, 7, 8 ), it can be seen that the causes of defects are mainly due to method and machine factors. After knowing the cause and root of the problem, it can be used as a basis for improvement. Next, the analysis of the cause of the defect is done with tools of why analysis, as in Table 3.

Table 3 shows each of the handicap priorities handled in terms of human factors, machines, methods, materials, and environment analyzed to the problem and its causes. Cause analysis identifies the root of the problem or cause of a mismatch in the process or product. The root cause of the leakage defect is due to the ineffective mold engine factor due to irregular mold maintenance and no cooling system regulator. The method factor is due to inaccurate parameter setting methods and ineffective x-ray examination methods.
Table 4 shows that the root cause of hole porous defects is due to the ineffective GBF engine due to eroded rotor conditions. The method factor is due to the incomplete method of controlling hydrogen gas.

Table 5 shows that the root cause of the oval defects is due to engine factors, the pins on the top mold and bottom mold are worn. The method factor is due to the inaccurate way of checking and measuring the dimensions of the wheels.

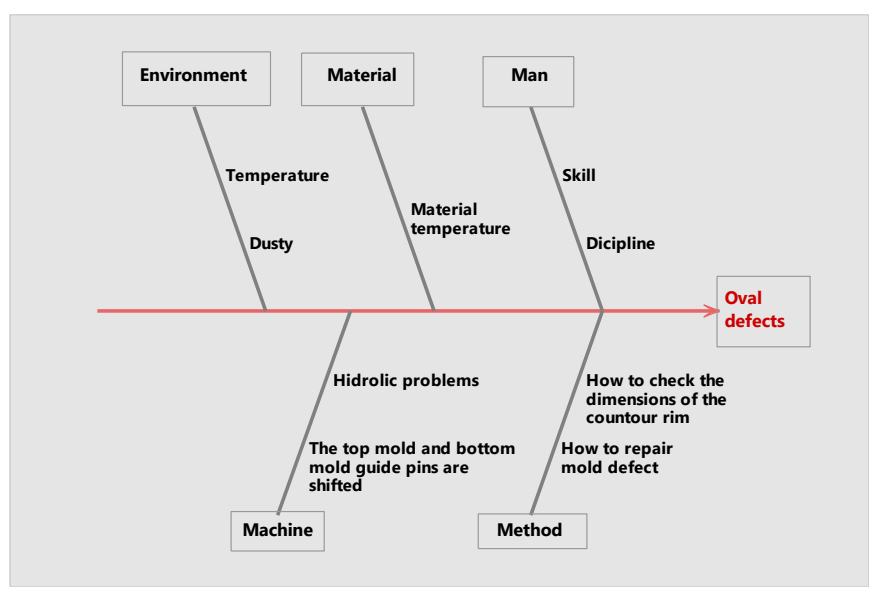

Figure 8. Cause and effect diagram oval defects

Table 3. Cause analysis of leak defects

\begin{tabular}{|c|c|c|c|c|}
\hline Factors & Potential failure mode & Why 1 & Why 2 & Why 3 \\
\hline Man & Less skilled, less discipline & Lack of experience & $\begin{array}{l}\text { Less understanding of } \\
\text { assignments }\end{array}$ & $\begin{array}{l}\text { Lack of training \& } \\
\text { coaching }\end{array}$ \\
\hline \multirow[t]{2}{*}{ Machine } & Mold condition & Less maintenance & Less control & $\begin{array}{l}\text { Less routine schedule } \\
\text { maintenance. }\end{array}$ \\
\hline & $\begin{array}{l}\text { The cooling system is not } \\
\text { optimal }\end{array}$ & $\begin{array}{l}\text { There is a scale that blocks the } \\
\text { flow of cooling water }\end{array}$ & Rarely cleaned & $\begin{array}{l}\text { There is no cooling } \\
\text { water discharge } \\
\text { regulator }\end{array}$ \\
\hline \multirow[t]{3}{*}{ Methode } & $\begin{array}{l}\text { Setting casting process } \\
\text { parameters }\end{array}$ & $\begin{array}{l}\text { Does not conform to standard } \\
\text { parameters }\end{array}$ & $\begin{array}{l}\text { The setting method is not } \\
\text { quite right }\end{array}$ & Lack of training \\
\hline & $\begin{array}{l}\text { Sending samples for } \mathrm{x} \text {-ray } \\
\text { examination is less effective }\end{array}$ & $\begin{array}{l}\text { Does not match the number of } \\
\text { samples and the results of } \\
\text { castings }\end{array}$ & $\begin{array}{l}\text { It is difficult to monitor the } \\
\text { number of wheel samples }\end{array}$ & \multirow[t]{2}{*}{$\begin{array}{l}\text { The wheels are not } \\
\text { numbered } \\
\text { Less socialized }\end{array}$} \\
\hline & $\begin{array}{l}\text { X-Ray methods are less } \\
\text { effective }\end{array}$ & $\begin{array}{l}\text { Defect's product is less } \\
\text { detectable }\end{array}$ & $\begin{array}{l}\text { X-ray examination rules are } \\
\text { not followed }\end{array}$ & \\
\hline Material & $\begin{array}{l}\text { The temperature of the molten } \\
\text { metal is not following the } \\
\text { standard }\end{array}$ & $\begin{array}{l}\text { Maintenance of the kitchen } \\
\text { ignition system is lacking }\end{array}$ & $\begin{array}{l}\text { Lack of control on } \\
\text { temperature settings }\end{array}$ & $\begin{array}{l}\text { Maintenance scheduling } \\
\text { not a routine }\end{array}$ \\
\hline Environment & Workspace hot and dusty & $\begin{array}{l}\text { Near furnaces and casting } \\
\text { machines }\end{array}$ & There is casting work & Radiation from engines \\
\hline
\end{tabular}

Table 4. Cause analysis porosity defects

\begin{tabular}{|c|c|c|c|c|}
\hline Factors & Potential failure mode & Why 1 & Why 2 & Why 3 \\
\hline Man & Less skilled & Lack of experience & $\begin{array}{c}\text { Less understanding of } \\
\text { assignments }\end{array}$ & $\begin{array}{c}\text { Lack of training \& } \\
\text { coaching }\end{array}$ \\
\hline Machine & $\begin{array}{c}\text { GBF (Gas Bubble Filtration) } \\
\text { machine }\end{array}$ & $\begin{array}{l}\text { Ineffective Nitrogen gas } \\
\text { flow settings }\end{array}$ & $\begin{array}{l}\text { The spread of Nitrogen gas } \\
\text { bubbles is uneven }\end{array}$ & $\begin{array}{l}\text { Rotor dimensions have } \\
\text { been eroded }\end{array}$ \\
\hline Methode & $\begin{array}{l}\text { The method of controlling the } \\
\text { degassing unit is less effective } \\
\text { A less effective way of } \\
\text { controlling hydrogen gas } \\
\text { content }\end{array}$ & $\begin{array}{l}\text { The temperature of the } \\
\text { molten metal is too high } \\
\text { Increased levels of } \\
\text { hydrogen gas into the } \\
\text { molten metal }\end{array}$ & $\begin{array}{l}\text { Check the condition of the } \\
\text { rotor dimensions is lacking } \\
\mathrm{H}_{2} \text { gas control method is not } \\
\text { quite right }\end{array}$ & $\begin{array}{l}\text { Periodically control the } \\
\text { degassing tool unit } \\
\text { There has been no revision } \\
\text { of the } \mathrm{H}_{2} \text { control method }\end{array}$ \\
\hline Material & Moist raw material & Moist storage place & Exposed to raindrops & Less protected by water \\
\hline Environment & Workspace hot and dusty & $\begin{array}{l}\text { Near furnaces and casting } \\
\text { machines }\end{array}$ & There is casting work & Radiation from engines \\
\hline
\end{tabular}


Table 5. Cause analysis oval defects

\begin{tabular}{lllll}
\hline Factors & \multicolumn{1}{c}{ Potential failure mode } & \multicolumn{1}{c}{ Why 1 } & Why 2 & Why 3 \\
\hline Machine & $\begin{array}{l}\text { The guide pins of the top mold and } \\
\text { bottom mold positions slide against each } \\
\text { other }\end{array}$ & $\begin{array}{l}\text { The position of the top mold } \\
\text { and bottom mold is not quite } \\
\text { right }\end{array}$ & $\begin{array}{l}\text { The top mold \& bottom mold } \\
\text { position is not centre }\end{array}$ & $\begin{array}{l}\text { There are worn } \\
\text { pins }\end{array}$ \\
\hline Method & $\begin{array}{l}\text { The way of visual inspection, dimension } \\
\text { measurement on as-cast wheels is less } \\
\text { effective }\end{array}$ & $\begin{array}{l}\text { No significant deviation was } \\
\text { detected }\end{array}$ & $\begin{array}{l}\text { Operators are less skilled in } \\
\text { inspection and measurement }\end{array}$ & Lack of training \\
Material & $\begin{array}{l}\text { The temperature of the molten metal in } \\
\text { the furnace is not standard }\end{array}$ & Settings are not quite right & $\begin{array}{l}\text { Lack of control on } \\
\text { temperature settings }\end{array}$ & $\begin{array}{l}\text { Maintenance } \\
\text { scheduling } \\
\text { periodically }\end{array}$ \\
\hline
\end{tabular}

\subsection{Improve phase}

The first step is to determine the value of the impact of the error on the process or product (severity), the frequency of occurrence of the error (occurrence), and possible detection methods that can now detect potential failures before the product is produced (detection). From the results of this determination, the RPN value will be obtained whose value is obtained by multiplying the value of Severity $x$ Occurrence $x$ Detection, as shown in the following Table 6:

Table 6. FMEA breakdown casting defects

\begin{tabular}{clccccc}
\hline $\begin{array}{c}\text { Potential } \\
\text { failure } \\
\text { mode }\end{array}$ & $\begin{array}{c}\text { Potential causes of the } \\
\text { effect }\end{array}$ & Severity & Occurrence & Detection & RPN & Proposed corrective action \\
\hline $\begin{array}{c}\text { Leak } \\
\text { defects }\end{array}$ & $\begin{array}{l}\text { Cooling system is less } \\
\text { effective }\end{array}$ & 6 & 6 & 6 & 216 & $\begin{array}{l}\text { Installation of the cooling water flow } \\
\text { meter. }\end{array}$ \\
\hline $\begin{array}{c}\text { Leak } \\
\text { defects }\end{array}$ & $\begin{array}{l}\text { The application of casting } \\
\text { and melting parameters } \\
\text { does not conform to the } \\
\text { standard }\end{array}$ & 7 & 6 & 5 & 210 & $\begin{array}{l}\text { Periodic control of the implementation of } \\
\text { parameter application }\end{array}$ \\
\hline $\begin{array}{c}\text { Porosity } \\
\text { motive } \\
\text { holes }\end{array}$ & $\begin{array}{l}\text { The operation of the GBF } \\
\text { engine degassing process } \\
\text { is not optimal }\end{array}$ & 6 & 7 & 6 & 252 & SOP for degassing process control is made \\
\hline $\begin{array}{c}\text { Porosity } \\
\text { motive } \\
\text { holes }\end{array}$ & $\begin{array}{l}\text { Mold cleaning methods } \\
\text { are less effective }\end{array}$ & 6 & 5 & 5 & 150 & $\begin{array}{l}\text { Check the cleaning method with 180the } \\
\text { wind, check the condition of the mold } \\
\text { after production in three parts: bottom } \\
\text { mold, upper core, die assy. }\end{array}$ \\
\hline Oval defects & $\begin{array}{l}\text { The mold position is } \\
\text { incorrect }\end{array}$ & 6 & 6 & 5 & 180 & $\begin{array}{l}\text { Repair and replace broken pins and normal } \\
\text { controls }\end{array}$ \\
\hline
\end{tabular}

The main cause of leakage defects is that the use of casting and melting parameters does not conform to the standard and the method of sending samples for X-Ray examination is less effective. Other potential causes are due to less skilled operators, less optimal cooling system effectiveness, and less experienced operators so that they do not understand the implementation of process parameters and work procedures.

The potential cause of the hole defect motive due to the GBF engine is not optimal. The GBF machine setting method does not match the standard parameters. The effectiveness of the cooling system is not optimal because sometimes the cooling water channel is due to blockage or scale. Also, some machines do not install a water flow meter to regulate the flow rate. Potential causes for oval defects are ineffective wheel alignment handling, steering pins at the top mold position and the bottom of the mold is damaged, so the mold position is incorrect.

\subsection{Control phase}

Efforts to make improvements at the control level with the aim of not improving the process. Production quality improvement data due to casting can be shown in the following Pareto diagram:

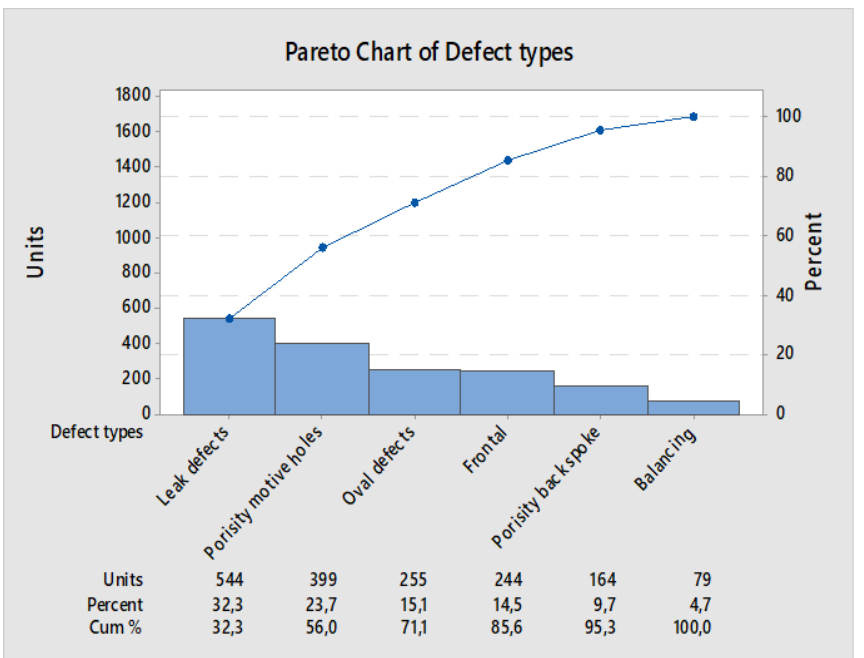

Figure 9. Pareto chart of the defect after improvement

Figure 9 shows that the Pareto chart, it is known that the largest number of defects are $32.3 \%$ leakage defects, $23.7 \%$ porous defects, $15.1 \%$ oval defects. Meanwhile, the line diagram represents the cumulative percentage of the total six defects. When compared to the percentage before (Figure 5) and after repair (Figure 9), there is a decrease in the percentage 
of three leaky, porous, and oval defects. The graph of production data control after quality improvement is as follows:

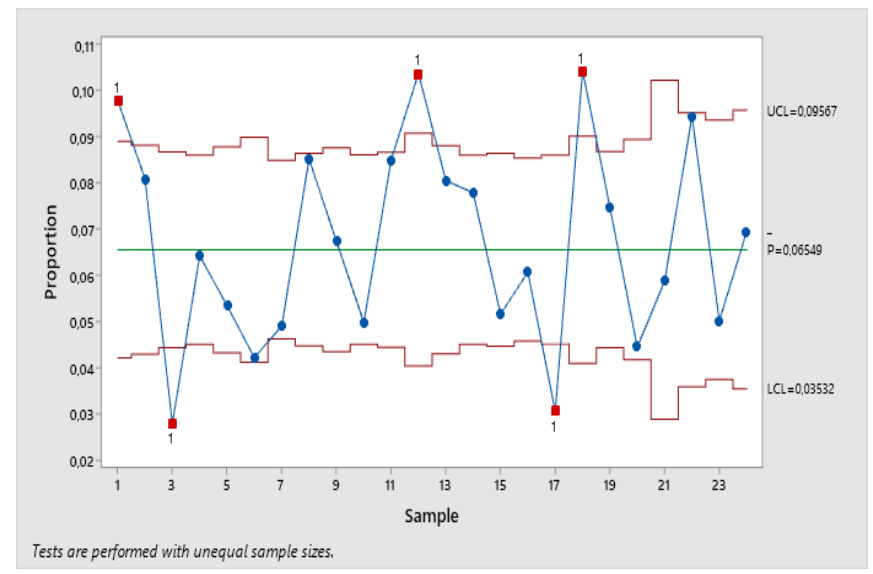

Figure 10. P-chart after quality improvement
In Figure 10 the control chart shows an increase in the wheel production process seen from the decrease in the number of points outside the control line. Before repairing were carried out there were 12 points that were beyond the limits of statistical control (Figure 4). The number of points outside the control limit after repairs were found 5 points, namely observations in samples $1,3,12,17$, and 18. Points still outside the control limit indicate that continuous improvement is still required to achieve more process stability.

Process capacity calculations are performed to determine whether corrective action taken for the process is sufficiently feasible. The pre-repair process capacity was 0.81 , after increasing it increased to $\mathrm{Cp}=1.46$. Based on evaluation indicators if $\mathrm{Cp}>1.33$ means process capability is improving. Product performance after improvement DPMO became 8.18 and the sigma value was 3.9.

The hypothesis t-test is done to ensure there are differences in the disability section in December 2019 and disability data in March 2020, so the results to analyze the hypothesis are as follows:

Table 7. Paired samples test

\begin{tabular}{|c|c|c|c|c|c|c|c|c|}
\hline & \multicolumn{5}{|c|}{ Paired Differences } & \multirow{3}{*}{$\mathrm{t}$} & \multirow{3}{*}{ df } & \multirow{3}{*}{$\begin{array}{l}\text { Sig. (2- } \\
\text { tailed) }\end{array}$} \\
\hline & \multirow[t]{2}{*}{ Mean } & \multirow[t]{2}{*}{$\begin{array}{c}\text { Std. } \\
\text { Deviation }\end{array}$} & \multirow[t]{2}{*}{$\begin{array}{l}\text { Std. Error } \\
\text { Mean }\end{array}$} & \multicolumn{2}{|c|}{\begin{tabular}{|c|}
$\begin{array}{c}95 \% \text { Confidence Interval of the } \\
\text { Difference }\end{array}$ \\
\end{tabular}} & & & \\
\hline & & & & Lower & Upper & & & \\
\hline \begin{tabular}{l|l} 
Pair & Proportion of defects on December 2019 - \\
1 & Proportion of defects on Maret 2020 \\
\end{tabular} & 059250 & ,044601 & ,009104 &, 040417 & ,078083 & 6,508 & 23 &, 000 \\
\hline
\end{tabular}

Table 7 shows the statistical data for paired samples test, hypothesis testing is carried out using the following rules:

Ha: There is a difference

If ( $t$ count $>t$ table) or value (Sig. $<0.05)$

Ho: There is no difference

If ( $\mathrm{t}$ count $<\mathrm{t}$ table) or value (Sig.> 0.05)

Based on the t-test statistical analysis, the decision is that $t$ $=6,508$ with a probability of 0,000 , therefore sig. $<0.05$, then $\mathrm{Ha}$ is accepted and Ho is subtracted, which means that there is a difference in the total number of wheel defects before and after repair with the DMAIC method.

Calculation of production costs due to a decrease in the percentage of defects, it is known that the production cost per wheel until the casting process is IDR. 175,000. Costs incurred due to inappropriate products are the total costs incurred until the casting process. Before and after improvements based on production and QC report in December 2019 and March 2020 stated that the number of defective products of 4,047 pcs and 1,685 pcs. So the production cost savings are: $(4,047$ pcs $1,685$ pcs $) \times$ IDR $175.000=$ IDR. 413.350.000.

\section{CONCLUSIONS}

This research highlights the benefits of DMAIC methodology in quality improvement. By simplifying way to practice this method with other tools support such as the 4M1E, Cp, p-Chart, DPO, DPMO, Sigma level, Pareto diagram, Fishbone diagram, Why why analysis and FMEA. Through the case study aluminium alloy wheels product quality improvement, DMAIC combined these tools and analyzed aluminum alloy whell defects in casting process, found rootcauses, and facilitated development of more sustainable ways to solve problems. Process performance was increased from
$\mathrm{Cp}=0.81$ to $\mathrm{Cp}=1.46$ and also the sigma level is increased from 3.6 to 3.9. The extremely impact reduces the defect ratio, and its finally creating the production costs saving by IDR 413.350.000 a month. Thus, the application of the DMAIC method shows that there is a significant improvement in product quality and it affects the cost savings of production. With respect to the objective of the case study, the DMAIC method is very effective in reducing the defect level and increasing the sigma level, however, at the end of the research further discussion is needed how for keeping the result. And the suggestion for the next researcher to make it better in terms of the quality we recommend for combining the DMAIC method with other quality tools like Taguchi and applying it to other automotive component industries.

\section{REFERENCES}

[1] Juran, J.M., Godfrey, A.B. (1999). Juran's Quality Hanbook. 5th ed. New York, United States of America: McGraw-Hill Companies. Inc, 1999.

[2] Supriyati, S., Hasbullah, H. (2020). Analisis cacat painting komponen automotive dengan pendekatan DMAIC-FMEA. Oper. Excell. J. Appl. Ind. Eng., 12(1): 104. https://doi.org/10.22441/oe.2020.v12.i1.009

[3] Pyzdek, T., Keller, P.A. (2010). The Six Sigma Handbook. 3rd ed. New York, United States of America: The McGraw-Hill Companies, Inc., 2010.

[4] Sunadi, S., Purba, H.H., Hasibuan, S. (2020). Implementation of statistical process control through PDCA cycle to improve potential capability index of drop impact resistance: A case study at aluminum beverage and beer cans manufacturing industry in Indonesia. Qual. Innov. Prosper., 24(1): 104. https://doi.org/10.12776/qip.v24i1.1401 
[5] Saryanto, S., Purba, H.H., Trimarjoko, A. (2020). Improve quality remanufacturing welding and machining process in indonesia using six sigma methods. J. Eur. des Syst. $\quad$ Autom., 53(3): 377-384. https//doi.org/10.18280/jesa.530308

[6] Pugna, A., Negrea, R., Miclea, S. (2016). Using six sigma methodology to improve the assembly process in an automotive company. Procedia - Soc. Behav. Sci., 221(2): 308-316. https://doi.org/10.1016/j.sbspro.2016.05.120

[7] Aized, T. (2012). Total Quality Management And Six Sigma, 1st ed. Croatia: In Tech, Janeza Trdine 9, 51000 Rijeka, 2012.

[8] Setiawan, D., Maryani, E., Fauziah, Y., Kartika, H. (2020). Does six sigma implementation suitable for smes? an exploratory study from Indonesia. J. Crit. Rev., 7(19): 148-163. https://doi.org/10.31838/jcr.07.19.279

[9] Ashary, H., Jaqin, C. (2016). Reducing downtime equipment in LPM machine line using DMAIC approach at an alloy wheel manufacturer in Indonesia. Int. J. Sci. Res., $5(7)$ : 740-744. https//doi.org/10.21275/v5i7.art2016205

[10] Purba, H.H., Aisyah, S. (2017). Quality Improvement and Lean Six Sigma: Meningkatkan Kualitas Produk dan Kinerja Perusahaan Menuju Zero Deffect, 1st ed. Yogjakarta: Expert, Ruko Jambusari 7A Yogjakarta, 2017.

[11] Godina, R., Pimentel, C., Silva, F.J.G., Matias, J.C.O. (2018). Improvement of the statistical process control certainty in an automotive manufacturing unit. Procedia Manuf., 17(6): 729-736. https://doi.org/10.1016/j.promfg.2018.10.123

[12] Montgomery, D.C. (2005). Introduction to Statistical Quality Control. 5th ed. New York, United States of America: John Wiley and Sons., 2005.

[13] Ford Motor Company. (2011). Failure Mode and Effects Analysis. Ford Motor Company This, 2011.

[14] Stamatis, D.H. (2015). The ASQ Pocket Guide to Failure Mode and Effect Analysis (FMEA), 1st ed. Milwaukee, Wisconsin: ASQ Quality Press, 2015.

[15] Tang, L.C., Goh, T.N., Yam, H.S., Yoap, T. (2006). Six Sigma, Advanced Tools for Black Belts and Master Black Belts, 10th ed. London: John Willey \& Sons. Ltd.
(UK), 2006.

[16] Costa, J.P., Lopes, I.S., Brito, J.P. (2019). Six sigma application for quality improvement of the pin insertion process. Procedia Manuf., 38(2): 1592-1599. https://doi.org/10.1016/j.promfg.2020.01.126

[17] Erbiyik, H., Saru, M. (2015). Six sigma implementations in supply chain: An application for an automotive subsidiary industry in Bursa in Turkey. Procedia - Soc. Behav. Sci., 195(2): 2556-2565. https://doi.org/10.1016/j.sbspro.2015.06.447

[18] Sharma, G.V.S.S., Rao, P.S., Babu, B.S. (2018). Process capability improvement through DMAIC for aluminum alloy wheel machining. J. Ind. Eng. Int., 14(2): 213-226. https://doi.org/10.1007/s40092-017-0220-z

[19] Reddy, K.S. (2014). Casting simulation of automotive wheel rim using procast. IOSR J. Mech. Civ. Eng., 11(6): 11-14. https://doi.org/10.9790/1684-11641114

[20] Kumar, E.S. (2015). A work study on minimize the defect in aluminium casting. Int. J. Emerg. Technol. Eng. Res., 3(1): 32-38.

[21] Sharma, C., Bhatia, O.S., Ucharia, V. (2015). A quality approach to control casting. Int. J. Adv. Technol. Eng. Sci., 3(6): 42-53.

[22] Trimarjoko, A., Saroso, D.S., Purba, H.H., Hasibuan, S., Jaqin, C., Aisyah, S. (2019). Integration of nominal group technique, Shainin system and DMAIC methods to reduce defective products: A case study of tire manufacturing industry in Indonesia. Manag. Sci. Lett., 9(13): 2421-2432. https://doi.org/10.5267/j.msl.2019.7.013

[23] Rozak, A., Jaqin, C., Hasbullah, H. (2020). Increasing overall equipment effectiveness in automotive company using DMAIC and FMEA method. J. Eur. des Syst. Autom., 53(1): 55-60. https://doi.org/10.18280/jesa.530107

[24] Pyzdek, T. (2003). The Six Sigma Project Planner, A Step-byStep Guide to Leading a SIx Sigma Project Through DMAIC, 6th ed. New York: McGraw-Hill Companies. Inc, 2003.

[25] Smętkowska, M., Mrugalska, B. (2018). Using six sigma DMAIC to improve the quality of the production process: A case study. Procedia - Soc. Behav. Sci., 238(2): 590596. https://doi.org/10.1016/j.sbspro.2018.04.039 